Article

\title{
Striving for Sustainable Development and the Coordinating Role of the Central Government: Lessons from Swedish Housing Policy
}

\author{
Kristina Söderholm ${ }^{1, *}$ and Elin Wihlborg ${ }^{2}$ \\ 1 History of Technology Unit, Luleå University of Technology, SE-971 87 Luleå, Sweden \\ 2 Department of Management and Engineering, Division of Political Science, Linköping University, \\ SE-581 83 Linköping, Sweden; elin.wihlborg@liu.se \\ * Correspondence: kristina.soderholm@ltu.se; Tel.: +46-920-491541 \\ Academic Editor: Tan Yigitcanlar \\ Received: 1 June 2016; Accepted: 11 August 2016; Published: 22 August 2016
}

\begin{abstract}
Housing plays an important role in the development of welfare policies and also often in achieving sustainability goals. There exists, however, implementation gaps between policies and practices in urban development and housing. Here it should be possible to draw lessons from policy implementations in the past. In this article we explore the strategies of the Swedish central government in implementing a social housing policy in the mid-20th century. The policy was successfully implemented in that it resulted in the rapid expansion and modernisation of the Swedish apartment stock in the late 1960s and early 1970s, and acute housingshortages and poor housing standards were overcome. The main lesson learned from the Swedish case study is the critical role of the central government in implementation throughthe strategic coordination of policy aims, instruments, stakeholders and interests throughout the implementation process. Although the central government could have used hard, almost authoritarian policy instruments to force the realisation of the new policy, it mainly used soft policy tools and focused on coordination. In the contemporary networked governance setting, the central government, like no other player, still has the potential to guide and coordinate implementation processes for the realization of sustainable housing visions.
\end{abstract}

Keywords: housing; central government; policy strategies; sustainability; historical lessons; Sweden

\section{Introduction}

Housing is often considered a core of social policy realisation since a dwelling constitutes a key hub in people's daily lives. Thus, policies on housing have played a crucial role in the development of welfare policies. Today these policies also often relate to sustainability, such as the EU program Urbact [1]. In Sweden there has further been a special national delegation (2009-2012) for sustainable urban development with a focus on housing (The delegation functioned as a forum for exchange of experiences between representatives for, among others, architects, planners and engineering consultants.) [2]. The design, construction and use of housing influence how a society can promote more sustainable ways of living and using the limited resources of the planet. Thus, sustainable housing policies advantageously cover a number of areas, ranging from the choice of building materials, construction technologies and housing types to residential heating methods and affordability. This implies our focus is on the environmental, economic and social aspects of sustainability. Furthermore, policies for more sustainable housing and daily activity patterns are tricky to implement [3-5], and we can identify implementation gaps from policies to practices in urban development and housing, gaps which have been identified by van Bueren \& De Jong [6] as caused by institutional rather than technological barriers. 
Sustainable housing development needs to combine and integrate all aspects of sustainability (ecological, social and economic development), and it thereby becomes integrated with a number of policy areas, where there in turn is a great risk of missing one or more policy aspects. The great number of actors participating in and contributing to the implementation of housing further tends to widen the implementation gaps. To bridge such gaps we need institutions which manage to frame interactions (between actors as well as policies and ideas) and innovative ideas where new conceptions of living in civil society can unsettle established practices [7]. There are examples of institutional arrangements which have succeeded in closing potential gaps from formulation to outcomes and which have contributed to the implementation of new housing policies. One such illustration is the rapid housing development following a social housing policy in Sweden from the 1940s to the mid-1960s. This policy culminated in the nation-wide "Million Program" (The "Million Program" is a collective term for the extensive housing construction carried out in Sweden during the period 1965-1974. The term stems from an ambition of the Social Democratic government to eliminate the housing shortage.) and the construction of over one million $(1,006,000)[8]$ new apartments in urban areas over ten years (1965-1974), and this in a country with a population of around 7.5 million (1960). Thus, this was a large-scale program where housing construction hit a record in terms of quantity and scale. Even though the Program in retrospect was quite extensively criticized for causing un-attractive neighbourhoods and, in extension, segregation [9], social improvement was a main goal behind the policy implying in turn that this Swedish case may provide interesting input for contemporary sustainability transitions. Hence, the goal was to overcome acute housing shortages, especially in bigger towns, and to improve the generally poor standard of the Swedish apartment stock by modernization and new-constructions in new residential areas, typically community centers. As a result, more than a quarter of Sweden's total housing stock was added over the 10-year-period, and a major portion of the apartment stock was modernized or newly constructed [10]. The housing program was in this way a key aspect of the advancement of the Swedish welfare state, with social and economic aims of equal living standards [11]. Also, although there were similar mass housing construction projects in several parts of Europe [12], the Swedish policy singled out through its focus on all social groups [13]. Consequently, there was large-scale production of new apartments as well as terraced and detached houses. Furthermore, although the central government had a stronger role in the Swedish society in the mid-20th century than is the case in Sweden and most other countries in the world today, it primarily took on a coordinative role to promote policy changes, and the case thus provides interesting input for contemporary challenges of sustainable housing policies. Hence, the Swedish central government realised the social housing policy by coordinating policy aims, instruments, stakeholders and interests, such as collaboration between authorities and broad commercial interests in the building and housing markets. This coordinative and collaborative strategy was in turn closely related to the general corporatism model of governance in Sweden at the time [14].

\subsection{Aim of the Article}

In this article we critically analyse the strategies of the Swedish central government to realise a social housing policy in the 1940s to the mid-1960s, culminating in the implementation of the nation-wide Million Program. We define implementation as the realisation of policies, from policies to practices-or, in other words, from policy formulation to planning, construction and consumption. We focus on policy instruments and in particular the role of the central government, its coordinative role and its potential to promote sustainable housing and urban development today. The article is organized around three research questions.

- How can governmental implementation strategies bridge policy gaps?

- What strategy was used by the Swedish central government to realize the social housing policy and related rapid modernisation and expansion of the Swedish apartment stock over the studied period?

- What lessons from the historical case study can inform policymaking and help generate more successful initiatives for contemporary sustainable housing development? 


\subsection{Methods}

We use the historical case study method since it allows lessons to be drawn from post-policy implementation and also offers a more long-term perspective on development today [15]. According to Meadowcroft [7], much can be learnt about sustainable transitions "by examining the politics of earlier political transitions (such as the advent of democracy and the genesis of the welfare state) as well as ongoing and historic struggles over issues of the environment and sustainable development" [7] (p. 75). Our case study has been chosen since it illustrates a process of successful policy implementation. Thus one million new apartments were rapidly constructed whereupon the aim of the policy, i.e., to overcome acute housing shortages and poor housing standards, was reached. As such, the Swedish social housing policy of the mid-20th century constituted a hub in the build-up of the welfare state.

The analysis is focused upon the strategy of the Swedish central government in the implementation of the social housing policy, i.e., after the idea of the need of an expanded and modernized apartment stock was established. The case study illustrates how the central government combined several different policy areas, and hereby it uncovers innovative implementation strategies and also opens up for implications for contemporary sustainable housing development. In previous literature, elements of the implementation of the Swedish social housing policy have been studied separately, such as the underlying ideas [16], or the planning and construction processes $[17,18]$ and their outcomes, the latter partly in terms of altered consumption patterns of Swedish households $[19,20]$. Still, the coordinating role of the central government, from planning to consumption, has not previously been in focus. This remark is largely valid also when considering international research on housing policies. We believe the Swedish experiences should be of generic interest for contemporary sustainability transitions where central governing bodies often still play a critical coordinating role.

The case study is mainly based on secondary sources from Swedish sociology and history. We also include complementary primary sources, mainly legislative documents and official statistics and reports. Parts of the historical material are presented in more detail in Söderholm $[19,20]$. The analysis has an inductive approach since the case study has been re-analysed to identify and uncover the different implementation strategies of the central government. The rapid construction process and its profound impacts on the welfare state draw our interest to the implementation strategy. Here we identify three critical aspects in the implementation of the program, i.e., land use, construction and consumption. These aspects should be identifiable in most implementation processes containing comprehensive technical design over large areas. Based on this categorization of the strategies in use, the analysis was developed in relation to the literature of public implementation. Since history is read through our contemporary setting when we search for lessons for the future, we will in next section discuss how historical experiences can inform our more networked governance context of policy making and implementation.

The article proceeds in three steps. In the next section (From government to ... ) we present a theoretical framework for the empirical analysis. In the third section (The big boom ... ) the case study is presented and analysed from three critical perspectives common for all urban development processes: land use, construction and consumption (as of housing). In the fourth section (Policy strategy for ... ) we highlight the key strategy of the Swedish central government and discuss lessons for contemporary efforts to implement sustainable housing policies. Finally, some concluding remarks are made.

\section{From Government to Governance-Contextualizing the Case}

Since the historical period covered in the case study there has been a general shift in how and by whom public policies are formed and implemented. Generally speaking, this has been identified as a shift from a government model to a networked governance structure. Governance as a concept captures the institutional change from a government-centred model of governance to a market-based or network-based governance model [21]. In the governance context, the government still plays a critical role but in a complex interplay with other actors, as well as in more open and networked 
relations [22]. If governments in the previous government context more or less alone could decide over politics, governments in the governance context rather co-ordinate actors and activities in the implementation process through soft policy instruments, such as by providing knowledge production, arenas for collaboration and general agreements on development aims [23].

\subsection{From Detailed Spatial Planning to a Focus on Urban Development}

Urban planning is embedded into more general policy aims related to the desired changes of society and is thus closely connected to policies on welfare and economic development. Urban development is in the same way not just about implementing new housing, but also comprises new ways of arranging everyday life [24]. Recently we have witnessed several examples of how urban planning has changed from merely regulative and managerial functions with focus on spatial arrangements and land use, to focus more on strategic issues in general, not least economic and sustainability aspects of urban development $[5,25]$. The building sector and housing development have also been framed into broader policy ambitions of sustainable practices, e.g., energy efficiency regulations [6].

The sustainabilitydiscourse emerged in building-related policies in the 1970s and 1980s, although it has been difficult to implement in the institutional setting of the building sector. Institutional settings are underlying arrangements to the action spaces of central governments [20,26], and the sustainability discourse is framed in institutional settings partly challenging former settings. A new and more networked institutional setting could provide (to the new discourse) more supportive policy strategies. We will discuss this further in the concluding discussion of the article.

\subsection{Policy Strategy_-Tools for Change}

Governments use policy strategies and instruments in processes of governing for common policy ambitions. These strategies and instruments are embedded in, and also a consequence of, the prevailing institutional settings. There is a broad palette of policy instruments available, from soft instruments as information, collaboration and knowledge production, to hard and forcing policy instruments as legislation (e.g., standards, bans etc.). Policy failures in turn generally revolve around the inability of weak policy instruments to carry through the necessary implementation [27]. Such implementation gaps are not uncommon, preventing plans from becoming a reality and actually changing the conditions of everyday life. One main explanation is the often large number of actors participating in the implementation phase, and lack of coordination among these [22]. The hard and forcing policy instruments are shaped by the central government, and like no other player in society it can help coordinate a large number of actors [28].

Spatial planning is in itself a policy instrument since it is usually an institutionally based, formal process of how and when to coordinate interests and decide upon land use and development: the access to and use of land is essential in processes of spatial planning. After the spatial plan is decided upon there are processes supporting also the design and realisation of constructions on land [29]. Here governments can play a more or less active role. They can provide strict regulations regarding permissions for, and design of structures. These are however commonly combined with soft regulations like economic subsidies and other forms of financial support systems. In the processes of design and construction, such as of a residential area, sociotechnical arrangements are further included which form and constrain the ways everyday life can take place. Thus, housing development opens for the implementation of more sustainable lifestyles [24]. However, there are often implementation gaps between policies and practices when it comes to more sustainable housing. In the following empirical analysis, three critical issues in the implementation of housing policies will be in focus, i.e., land use, construction and consumption. 


\section{The Big Boom Social Housing Policy-Making Room for the Good Life of the Welfare State}

The historical period of large-scale housing development and social housing policy took place in the heyday of the Swedish welfare state. Through the process of housing development most Swedes became part of the growing welfare state as the housing policy was directed at all social groups [11]. We will analyse this transition by focusing on policies regarding land use/ownership, construction and consumption of housing, beginning with the discussion under the heading Land use as a planning tool. First, however, some further background/context for the case is presented.

\subsection{Contextualising Swedish Social Housing Policy}

Swedish social housing policy was based on ideas on satisfactory housing with improved housing standards for all [30]. Beginning in the 1940s, there was a housing shortage in the bigger cities in Sweden, largely due to structural rationalizations in Swedish industry with accompanying resettlement and household splintering [31]. Actualized by a general socioeconomic development and a changed and more supportive role of the state towards the family from the 1930s and onwards, the central government promoted development with an extensive social housing policy in the mid-20th century. Several public investigations are evidence of major state ambitions, such as "The Housing-Social Investigation I and II" in 1945, and "Increased Standards of Housing" in 1965. The latter investigation launched the Million Program with major effects on the Swedish apartment stock and appearance of the average Swedish town. Not only did the number of apartments in the Swedish apartment stock double, smaller apartments also made room for bigger ones; apartments bigger than two rooms (plus kitchen) increased in proportion to the total Swedish apartment stock from one-fourth to almost three-fourths in the first few post-war decades [17] (p. 234) [32].

In parallel to the implementation of the social housing policy and the Million Program, Swedish public administration continuously developed and the municipal administration of urban planning and other local administration became ever more professional and efficient [33]. There is a long tradition of extensive local autonomy in Swedish governmental structure; municipalities comply with the legal framework decided by the central government but have the right to make independent decisions and raise taxes from the local residents to fulfill its tasks [34]. The Local Government Act and the so-called Special legislation have provided municipalities with ultimate responsibility for many important societal functions, such as social care, schools, housing, water and sewage, sanitation, planning and construction issues, etc. Along with the local autonomy there has also been a long tradition of a local planning monopoly in Sweden. This has limited the central government's options to force specific land use at the local level at the time of the implementation of the social housing policy and the Million Program in the 1960s and 1970s. Thus, as is illustrated below, the central government instead developed policy instruments that promoted and coordinated urban planning, including housing development and the implementation of social housing reforms.

\subsection{Land Use as a Planning Tool}

Land use and ownership of land are critical in situations where policies with central elements of recurring and comprehensive technical design over large areas are to be implemented. Thus, the post-war social housing policy of the Swedish central government presupposed a large contiguous disposable surface. The central government formed conditions for this and at the same time for municipal entrepreneurship through the creation, in 1947, of the "Construction Act" and the "Housing Provision Act". Following the "Construction Act" local authorities were given a de facto local planning monopoly, whereas the overriding responsibility for the provision of housing, at least for planning and initiation, was put in the hands of the municipalities with the "Housing Provision Act". In comparison with other national systems, the Swedish local planning monopoly has a strong tradition which was further strengthened into the 1980s. The final decision right over land use was granted to Swedish municipalities through the Planning and Building Act of 1987 [35]. This is clearly mirrored in a central 
wording of the law: "it is a municipal concern to plan the use of land and water" [35] (1st chapter, $2 \S$, authors' translation) [36].

In connection with the Million Program in the 1960s, the Swedish central government noted that it was crucial for municipalities to also own land on a large scale in order to become independent of other land owners and to guide the construction with the help of the local planning monopoly. In 1967, the central government therefore began to support the land acquisition of municipalities, partly by giving them right of first refusal on sales of property required for agglomeration or related device (the Municipal Preemption Right Act) [37], and partly by establishing a state loan fund for municipal land acquisition (Loan Fund for Municipal Land Acquisition) [38]. This policy change had profound impacts. For instance, in 1975, the State Council for Building Research, in a study of the housing policy in West Swedish municipalities, noted that since the 1960s, municipalities had constructed $95 \%$ of the new houses on Greenfield sites, and further owned $80 \%$ of the land on which construction was done [39].

This indicates that the central government used hard legislative policy strategies to give the municipalities the capacity to get access to land and thereby promote housing construction and strategic locations for this. There were also long-term impacts from these policies as the municipalities still had the power to plan and guide where and by whom urban construction took place.

\subsection{The Construction of Residential Areas}

The new housing policy, which began in the 1940s, favoured public and cooperative housing companies instead of private ones. With such a policy the central government hoped to promote the construction of larger units while facilitating the rationalization of construction through larger planning, design and operation. Through this early housing policy, private developers lost their monopoly in the housing market. Instead the influence of public and cooperative housing companies increased. The size and expertise of the public housing companies varied and, depending on this, also how much they actually participated in the construction process. The largest of the public housing companies, however, typically had their own architectural office and carried through the construction themselves as well as kept their own "element factories" [18]. The initially contradictory views concerning housing construction in public or private management evened out over time and became stable in the 1950s, when construction, after all, largely was conducted by private constructors on behalf of public, cooperative and private developers. This market situation, with private companies largely producing for public and cooperative developers, has characterized housing construction in Sweden throughout the 20th century [17].

In pursuit of ever greater planning, design and operation of housing construction in the 1960s, the central government developed the so-called "Total-contract reform" where the contractor (often a municipal entrepreneur) handed over all engineering and production to a single producer. The reform grew out of the need to construct as many houses as quickly and cheaply as possible, and it helped adjust planning for the requirements of the production apparatus. Thus, housing construction became planned in close cooperation between the contractor, the local planning authorities and the design engineer/constructor, and was therefore interwoven in the general town-planning process in contrast to earlier procedures where town planning preceded construction. It now became common with far-reaching collaboration between the parties before the city plan was drawn up. In this way the plan was better adapted to production, and the construction company had more influence on the design of the plan [17].

Beginning in the mid-1940s, the Swedish central government also promoted the implementation of the social housing policy through legislation allowing favorable government grants and priority access to credit for contractors and designers/constructors. To obtain loans from the National Building Loan Agency, the buildings were required to meet specified standards in equipment and size. Conditions were specified in the standard collection Good Housing ("God Bostad") issued by the National Housing Board between 1964 and 1976. Every aspect of the apartment was addressed here, from measurement 
rules for the size of rooms, sanitary facilities and standard cabinets, to closets and work spaces in the kitchen [40]. Through this diffusion of knowledge and standardization, not only were good housing standards guaranteed but standardization also benefited indirectly from the rationalization and industrialization of the construction of multi-story buildings, something that was technically necessary for the large-scale Million Program to succeed. The standardization of the apartments contributed to the repetition that characterizes industrial production. The Million Program of course also meant a steady and high demand for a long time which in itself was stimulating for the investments that were necessary for the rationalization.

The rationalization and industrialization of the construction process took off in the 1950s, when wages increased and there was a general shortage of construction workers. It was primarily about the introduction of machinery and equipment in the construction process, such as the tower crane, which enabled the use of re-usable steel moulds instead of wood moulds in the concrete-casting process: the number of tower cranes in Sweden increased from 20 in 1950 to about 5000 by 1970 [41,42]. Given the large-scale transformation of the apartment stock that lay ahead it was of essential significance to the central government that mechanization and rationalization developed further. In the 1950s, the central government thus pursued development through direct intervention in production. This was accomplished mainly through economic policy instruments, such as different forms of loans and allowances. These made it possible for contractors and designers/builders to initiate large projects with long series (repeated production results), and thus created favourable conditions for series-produced components and rationalized construction. One example of such a policy is the "machine-loan fund" established in 1952, from which builders could apply for loans for financing equipment in factories and at construction sites. Up to $80 \%$ of the costs could be covered by loans, and the majority of the funding went to cranes [43].

In the 1960s, the Swedish central government further initiated experimentation for industrialized building where participants could get advance notice of guarantees for the financing of larger projects, planned and projected for more than 1000 apartments and with a high degree of standardization. Production plans should represent smooth continuous production. Design, procurement and construction had to be coordinated for the entire project, which should have a high degree of uniformity with limited variation and number of house types. Manpower consumption should furthermore be relatively minor and production costs low compared with normal costs on site [44-46].

Based on the land use policies described above, making land available for larger scale construction of new residential areas, the central government further facilitated rationalized and industrialized housing construction processes. This was promoted mainly by soft policy instruments, such aseconomic subsidies and other forms of financial support systems. The central government also promoted development by knowledge production and diffusion (the Swedish standard) and by creating arenas for collaboration, such as between the contractor, local planning authorities and constructor.

\subsection{The Consumption of Housing}

The implementation of the social housing policy also required generally changes to consumption behaviour. Thus the Swedish central government created conditions for widespread consumption/use of the new residential areas through an extensive housing allowance policy in combination with legislative changes concerning rent control, protected tenancy and local housing authorities [31]. The effects were far-reaching in terms of large share of rental housing: even today, Sweden has a larger proportion of rental housing than other European countries [47].

Housing allowance and housing policy became part of the social policy already in the 1940s, when it was recognized by the Swedish central government that there was social inequality in the housing market. Also rent control was introduced in the 1940s, based on the idea that it would not only benefit the tenants, as increased rents were considered to lead to higher wage demands and thus inflation. For the same purpose the central government introduced loans and grants for residential properties in order to minimize capital costs and ultimately rents for housing [17]. This funding was, 
as previously mentioned, related to economic and technical requirements, the "Swedish standards", whereupon each project applying for a loan during the first half of the 1940s was reviewed by the National Agency for Construction Loans (Statens byggnadslånebyrå). At the time, however, this represented more than a social housing policy with the objective to improve poor housing conditions. The background was also a wish to deal with the current unemployment rate [48]. The social housing measures of the 1940s had immediate effects on the economic opportunities of ordinary Swedes to improve their standard of housing. In the National Social Housing Investigation of 1945 it was stated that while just over $20 \%$ of the population could afford to rent a modern two-room apartment in 1933, this share had increased to over 30\% in 1939, and to as much as 60\% in 1945 [48] (pp. 224-229).

A main theme in the Swedish central government's idea of the welfare state and further in the realization of the Million Program was to reform by political means the living conditions of women, men and children. (This reform was also implemented in several policies other than the social housing policy, such as from pension and social and health insurance policies, to education, labour market and tax policies.) A particularly distinctive area of reform in this context concerned attempts to equalize not only economic and social conditions, but also unequal relations between women and men [49]. The Million Program was thus realized through so-called neighbourhood units, apartment complexes with housing amenities in the form of laundries, playgrounds, day-care centres etc., which facilitated household work and enabled women to work out of the home. In the centre of the neighbourhood unit several other housing complements merged, such as the post office, grocery stores, a dentist and medical centre etc. Here, a number of everyday matters could be conducted at a single location and within walking distance, and this helped rationalize housework further. Embedded in the realisation of the Million Program and the welfare state was further also other changed consumption patterns of the residents. The new apartments were constructed considerably larger than previous general housing. Thus, a large number of Swedes increased their consumption of living space. Also, the neighborhood units were often located in urban peripheral areas with a large general increase in car use as consequence [17].

With the consumption of apartments in the new residential areas further followed an increased consumption of a number of system-provided products, i.e., water and sewage, central heating, electricity and gasoline. To reconnect to the rationalization and industrialization in the construction of multi-story buildings during the realization of the Million Program, much of the means and results are lost in Sweden today due to the relatively modest market for multi-story buildings since the early 1970s [46]. Some knowledge and competence on rationalized and industrialised construction have however remained within the construction process of detached houses. Thus, rationalization has also benefited private builders of detached houses.This is especially true when it comes to the many catalogue houses, which constituted a very large proportion of the extensive growth in the construction of detached houses during the first half of the 1970s, from about 20,000 to almost 50,000 houses constructed per year [50]. The large increase in the construction of detached houses would not have taken place had it not been for the growing abundance of catalogue houses produced in rationalized and industrialized ways, and thus at reasonable costs: about two-thirds of the detached houses built in the early 1970s were catalogue houses, where house-elements were constructed at the factory for assembly at the building site. The central government promoted the development in the construction of detached houses, and especially of catalogue houses, also by claiming "Swedish standards" with respect to dimensions, design and quality for doors, windows, cabinetmaking, etc. Said standards then formed the basis for outlines for type-plans issued by the national Technical Office of the Royal Housing Committee (established in 1948), and for sale to those applying for home loans. (The central government promoted the increase in the construction of detached houses also through favourable tax conditions and a changed monetary policy making it easier to obtain loans.) The type-plans offered useful technical solutions and work instructions previously accessible only to consultants with 
expertise in structural engineering. They were abundantly utilized by both individual house builders and producers of catalogue houses [51,52].

To conclude, already in the 1940s the central government actively took responsibility for making housing affordable but still with good standards of living. Thus, the consumption of housing relied on a comprehensive housing allowance policy in combination with legislative changes when it came to rent control, protected tenancy etc. New institutional arrangements aimed at counteracting social inequality in the housing market as well as, initially, inflation. Loans and grants (including technical requirements) for residential properties (later also for individual builders of detached houses) were also included in this arrangement. The new residential areas reformed the living conditions of the average Swedish household, not least for the women. They further allowed for new forms of consumption and everyday life, which had more general implications for the development of society. Housing is therefore a critical issue for the development of societies in more sustainable ways.

\section{Policy Strategies for Sustainable Housing-Contemporary Implications}

The processes described above illustrate a strategy of comprehensive and conscious coordination of policy aims, instruments and stakeholders. It further illustrates the importance of access to land, a coordinated and highly standardized construction process, a well-arranged funding system supporting the construction and the consumption of the new residential areas. Through this coordinative strategy, the Swedish central government came to play a critical role for the realisation of the ambitious policy aims, i.e., over one million new apartments were constructed and the general housing standards in terms of living space and connectivity to central systems for water/waste water and heat improved considerably for all social strata of Swedish citizens.

We argue that this case study is highly relevant to sustainable housing development today. The role of the central government was critical to the outcome in the historical case, the role of the central government is critical also in contemporary network-based governance settings since the coordinative strategy is as relevant today. No other player in society has the instruments to take on an equally coordinative role.

The coordinative strategy of the central government permeated the entire implementation. The central government thus promoted the critical land aspect as well as the equally critical construction and consumption aspects, whereupon policy gaps were prevented in those three different critical aspects. Contemporary sustainability ambitions are seldom coordinated this way. Instead, the networked governance approach and the broad aims of sustainability policies of today open up for policy gaps. Furthermore, through the implementation of the Million Program more than one policy aim were simultaneously addressed. The housing policy had a broad approach to the good life, gender equality and convenient patterns of everyday life. Similar ambitions are often expressed also in sustainable development policies today, although they are seldom addressed through implementation strategies [53]. They are further often spoken of separately as policy aims and are thus not addressed jointly as in the implementation of the Swedish Million Program.

Of central importance throughout the implementation process in Swedish housing policy was further the intra-government coordination between the central government and the municipalities as these were the urban planning authorities. The municipalities were also supplied with new competencies. Thus, they got access to land and funding and tools to provide an effective arena for collaboration between the contractor, the local planning authorities and the constructor. In this way both policy instruments and stakeholders were coordinated. This intra-governmental coordination was essential for successful governance. Here there are also lessons to be drawn for the contemporary European multi-level governance setting, on the role of central government actors to coordinate and promote change in line with policies within a more networked governance structure.

The central government, through the institutional arrangement at the time, had an option to use hard, almost authoritarian policy instruments to force the realisation of the new policy. However, as shown above, the Swedish central government mainly used soft policy tools and focused on the 
coordination of interests, financial support and standardisation to encourage efficient construction processes and affordable housing, and by doing so, the housing policy was pragmatically implemented. In contemporary networked governance setting, and as argued also by Bulkeley \& Betsill [54], the action space of the central government is more constrained both when it comes to available policy instruments and coordination opportunities. Still, there is reason to also ascribe the central government a more influential role in contemporary networked governance setting. Thus, central governments (now also at the European level) ought to have the capacity to coordinate policy instruments and stakeholders to match and reinforce each other for successful implementation and to avoid policy gaps. Coordination should also include market actors, such as construction firms and housing companies, and here the stable partnership of private and public actors illustrated in the case and which further characterized several policy areas in Sweden in the mid-1900s [55] can serve as a model. This partnership facilitated knowledge-exchange in processes of planning, standardisation and rationalised production, which in turn laid grounds for mutual trust and investments between the actors. In contemporary sustainability discourse there is a need for similar intra-organisational collaboration to avoid policy gaps [53]. In this context we should further emphasize the potential of financial support (loan funds etc.) to realise policy. This was used rather extensively by the Swedish central government, as shown in our case study, and should be a capacity that central governments, like no other player in society, still hold today.

Although the traditionally strong Swedish government in promoting a physically constructed social welfare society has been noted in previous research, the conscious, coordinative and all-embracing approach of the central government has not been previously addressed. The coordination and involvement of both public and private stakeholders with different expertise to enforce knowledge development was key to the rapid housing expansion. There was also a continuous evaluation (from the public funding and related standards requirements) built into the implementation.

Historical cases like this further remind us of the long-term perspectives of societal development. When looking back on policy decisions made forty or more years ago, and while still living with the effects of these decisions in the environment around us, we are reminded of the need to also consider the impacts of contemporary policy decisions forty years into the future. In this context, the need to include the well-being of future generations becomes apparent, and we might even have to construct "stakeholders" to incorporate the interest of future generations in the planning process. The historical case illustrates how housing was seen as a key for future welfare and the good life of citizens, particularly women and children. However, in the planning of the Million Program no one really asked the women and children (or the men) what they wanted. The Program has also been criticized for the lack of influence from future residents in the planning process [11]. The networked governance context opens theway for more voices to be heard and for a deliberative participation (which, on the other hand, may restrict coordination). There are further demands for alternative, more sustainable and less consumption-focused lifestyles. The lessons learned about standardization and efficient work organisation may here allow new, innovative ways of arranging implementation processes, from planning to consumption. There is also potential for central governments to promote more sustainable lifestyles by, for example, planning for increased space for urban gardening, pedestrians and improved access to public transportation in residential areas. Thus, by considering the "whole use" of a residential area there is potential for arranging new and more sustainable patterns of consumption and lifestyles. Overall we argue that the lessons learned from the Swedish case are also important for coordinating sustainable housing development today; there are ambitions to once again make housing a hub of welfare and sustainability, and there is potential to further improve implementation.

\section{Final Remarks}

If sustainable development is considered as important today as the promotion of good housing was then, there is potential to actually transform and develop new sustainable housing. In line with the historical case, the central government can take on a more active, coordinative and all-embracing role in the implementation process, such as by focusing on land use, construction and consumption in housing 
development. There is a need for central governments today, possibly promoted by the EU, to step into the networked governance structures with well-coordinated policy strategies to address the ecologic, social and economic sustainability of housing. The key lesson learned is that the central government can take on the task of focusing on and coordinating a variety of related policies and stakeholder interests in the development process. In the same way, the central government, again, like no other player in society, is capable of translating general policies into supportive institutional structures and efficient and implementable policy tools and instruments. The overall efforts in several EU countries and elsewhere for sustainable housinghave the potential to be as rapid and large-scale as in the studied case, if the central government and perhaps also the EU take on the role of coordinatingpolicies, actively promoting implementation and bridging policy gaps.

Author Contributions: Kristina Söderholm contributed to acquisition of data, design of research, conducting of analysis and the literature review. Elin Wihlborg contributed to theoretical framework, structuring the format and conducting of analysis.

Conflicts of Interest: The authors declare no conflict of interest.

\section{References}

1. Connecting Cities Building Successes. Available online: http://urbact.eu/who-we-are (accessed on 4 August 2016).

2. Delegationen för Hållbara Städer. Available online: http://www.hallbarastader.gov.se/Bazment/ hallbarastader/sv/start.aspx (accessed on 4 August 2016).

3. Koebel, C.T. Sustaining Sustainability: Innovation in Housing and the Built Environment. J. Urban Technol. 1999, 6, 75-94. [CrossRef]

4. Campbell, S. Green Cities, Growing Cities, Just Cities? Urban Planning and the Contradictions of Sustainable Development. J. Am. Plan. Assoc. 1996. [CrossRef]

5. Healey, P. Urban Complexities and Spatial Strategies; Routledge: Oxford, UK, 2007.

6. Van Bueren, E.; De Jong, J. Establishing sustainability: Policy successes and failures. Build. Res. Inf. 2007, 35, 543-556. [CrossRef]

7. Meadowcroft, J. Engaging with the politics of sustainability transitions. Environ. Innov. Soc. Trans. 2011, 1, 70-75. [CrossRef]

8. Statistics Sweden. Statistical Yearbook; Statistics Sweden: Stockholm, Sweden, 2010.

9. Borevi, K. Bostadspolitiken och frågan om boendesegregation. In Den Nya Bostadspolitiken; Lindbom, A., Ed.; Boréa: Umeå, Sweden, 2001; pp. 291-324. (In Swedish)

10. Hall, T. Rekordåren: En Epok I Svenskt Bostadsbyggande; National Board of Housing: Karlskrona, Sweden, 1999. (In Swedish)

11. Bengtsson, B. Housing as a social right: Implications for welfare state theory. Scand. Political Stud. 2001, 24, 255-275. [CrossRef]

12. Turkington, R.; Kempen, R.; Wassenberg, F.A.G. (Eds.) High-Rise Housing in Europe: Current Trends and Future Prospects; DUP Science: Delft, The Netherlands, 2004.

13. Arnstberg, K.-O. Miljonprogrammet; Carlssons: Stockholm, Sweden, 2000. (In Swedish)

14. Rothstein, B. Explaining Swedish Corporatism: The Formative Moment. Scand. Political Stud. 1992, 15, 173-191. [CrossRef]

15. Söderholm, K.; Wihlborg, E. Policy for Sociotechnical Transition: Implications from Swedish Historical Case Studies. J. Environ. Policy Plan. 2015, 17, 452-474. [CrossRef]

16. Hirdman, Y. Att Lägga Livet Tillrätta: Studier I Svensk Folkhemspolitik; Carlsson: Stockholm, Sweden, 1989. (In Swedish)

17. Franzén, M.; Sandstedt, E. Välfürdsstat Och Byggande: Om Efterkrigstidens Nya Stadsmönster I Sverige; Arkiv förlag: Lund, Sweden, 1993. (In Swedish)

18. Ramberg, K. Allmännyttan: Välfärdsbygge 1850-2000; Byggförlaget in cooperation with the Swedish Association of Public Housing Companies: Stockholm, Sweden, 2000. (In Swedish)

19. Söderholm, K. Housing, public policy and the environment in a historical perspective: Lessons from Swedish post-war society. Int. J. Sustain. Soc. 2013, 5, 24-42. [CrossRef] 
20. Söderholm, K. Policy-driven socio-technical structures and Swedish households' consumption of housing and transport since the 1950s. In Environmental Policy and Household Behaviour: Sustainability and Everyday Life; Söderholm, P., Ed.; Earthscan: London, UK, 2010; pp. 149-172.

21. Pierre, J.; Peters, G. Handbook of Public Policy; Sage: London, UK, 2006.

22. Sørensen, E.; Torfing, J. (Eds.) Theories of Democratic Network Governance; Palgrave Macmillan: Basingstoke, UK, 2008.

23. Jacobsson, P.J.; Sundström, G. Governing the Embedded State: The Organizational Dimension of Governance; Oxford University Press: Oxford, UK, 2015.

24. Graham, S.; Marvin, S. Splintering Urbanism: Networked Infrastructures, Technological Mobilities and the Urban Condition; Routledge: London, UK, 2001.

25. Albrechts, L. Strategic (spatial) planning re-examined. Environ. Plan. B 2004, 31, 743-758. [CrossRef]

26. Greenwood, D. The challenge of policy coordination for sustainable sociotechnical transition: The case of the zero-carbon homes agenda in England. Environ. Plan. C 2012, 30, 162-179. [CrossRef]

27. Vedung, E. Policy Instruments: Typologies and Theories. In Carrots, Sticks and Sermons, Policy Instruments and Their Evaluation; Bemelmans-Videc, M.-L., Rist, R., Vedung, E., Eds.; Transaction Publishers: New Brunswick, NJ, USA, 1998.

28. Pollitt, C.; Bouckaert, G. Continuity and Change in Public Policy and Management; Edward Elgar Publishing: Cheltenham, UK, 2011.

29. Vedung, E. Statens Markpolitik, Kommunerna Och Historiens Ironi; Studieförbundet Näringsliv och Samhälle (SNS): Stockholm, Sweden, 1993. (In Swedish)

30. Scott-Webber, L. The Nordic Perspective on Accessibility: Building a Society for All. J. Urban Technol. 1996, 3, 43-57. [CrossRef]

31. Bladh, M. Bostadsförsörjningen 1945-1985: Det Industriella Byggandets Uppgång Och Fall. Ph.D. Thesis, School of Economics and Commercial Law, Gothenburg University, Gothenburg, Sweden, 1991. (In Swedish)

32. Statistics Sweden. Statistical Yearbook; Statistics Sweden: Stockholm, Sweden, 2005.

33. Hanes, N.; Wikström, M.; Wångmar, E. Municipal Preferences for State-imposed Amalgamations: An Empirical Study Based on the Swedish Municipal Reform of 1952. Urban Stud. 2012, 49, 2733-2750. [CrossRef]

34. Granberg, M. Local governance 'in Swedish'? Globalisation, local welfare government and beyond. Local Gov. Stud. 2008, 34, 363-377. [CrossRef]

35. Plan-och Bygglagen. Planning and Building Act of 1987; The National Board of Housing, Building and Planning: Karlskrona, Sweden, 2005.

36. Strömberg, T. Bostadspolitik: En Historisk Parentesin Den Nya Bostadspolitiken; Lindbom, A., Ed.; Boréa: Umeå, Sweden, 2001. (In Swedish)

37. Swedish Government. Förköpslagen [Municipal Preemption Right Act] SFS: 1967; Swedish Government: Stockholm, Sweden, 1967; Volume 868. (In Swedish).

38. Swedish Government. Lånefonden för Kommunala Markförvärv [Loan Fund for Municipal Land Acquisition] 227 prop. 1968:1 Annex 13; Swedish Government: Stockholm, Sweden, 1968. (In Swedish)

39. Svensson, R. Analys av Prisutvecklingen på Bostadsmark I Västkustregionen: Markprisbestämmande Faktorer I ett 60-Tal Västsvenska Kommuner; Statens Råd för Byggnadsforskning I Samarbete Med Göteborgs Universitets Geografiska Institutioner: Stockholm, Sweden, 1975. (In Swedish)

40. Roos, B.; Gelotte, H. (Eds.) Hej Bostad: Om Bostadsbyggande I Storstockholm 1961-1975; Stockholm County Administrative Board: Stockholm, Sweden, 2004. (In Swedish)

41. Björk, C.; Kallstenius, P.; Reppen, L. Så Byggdes Husen 1880-1980. Arkitektur, Konstruktion och Material I Våra Flerbostadshus under 100 år; Byggforskningsrådet, BFR/Stockholms Stadsbyggnadskontor: Stockholm, Sweden, 1983. (In Swedish)

42. Marmstål, F. Byggarna och Maskinerna_Folke Marmstål Berättar för Nils Nordberg; Byggförlaget: Stockholm, Sweden, 1992. (In Swedish)

43. Bergström, H.; Carlson, A.; Svenson, G. Bostadspolitiken; Tiden: Stockholm, Sweden, 1968. (In Swedish)

44. Swedish Government. Byggandets Industrialisering [The Industrialization of Construction], SOU 1971; Swedish Government: Stockholm, Sweden, 1971; Volume 52. (In Swedish) 
45. Statens råd för Byggnadsforskning [Government Council for Construction Research]. Monteringsbyggda Flerfamiljshus: Rapport Från Moby-Kommittén Med Förslag Till Forskningsprojekt; Statens Råd för Byggnadsforskning: Stockholm, Sweden, 1975. (In Swedish)

46. Hyll, H.; Lessing, J. Industrialisering av Bostadsbyggandet under 1900-Talet; Lund Institute of Technology: Lund, Sweden, 2004. (In Swedish)

47. Isaksson, A. När socialdemokratin blev statsbärande. In Då Förändras Sverige: 25 Experter Beskriver Drivkrafter Bakom Utvecklingen; Giertz, E., Ed.; SNS: Stockholm, Sweden, 2008; Volume 1, pp. 39-154. (In Swedish)

48. Swedish Government. Bostadssociala Utredningen [National Social Housing Investigation], SOU 1945; Swedish Government: Stockholm, Sweden, 1945; Volume 63. (In Swedish).

49. Lundqvist, Å. Family Policy Paradoxes. In Gender Equality and Labour Market Policies in Sweden 1930-2010; Policy Press: Bristol, UK, 2011. (In Swedish)

50. Wigren, R. Bygg-och bokostnader-Historisk utveckling och framtidsutblick. In Bostadsmarknaden på 2000-Talet; Andersson, Å.E., Ed.; SNS in Cooperation with SABO/Swedish Association of Public Housing Companies and IFFS/Institute for Future Studies: Stockholm, Sweden, 1997; pp. 206-245. (In Swedish)

51. Engfors, C. Folkhemmets bostäder 1940-1960. In Svenskt Bostadsbyggande under 1940- och 50-Talen; Museum of Architecture: Stockholm, Sweden, 1997. (In Swedish)

52. Gabrielson, I.; Ringmar, C.-I. 40 Sätt att Bygga Småhus: En Undersökning av Typhusfabrikanternas Standardleveranser; Statens Institut för Byggnadsforskning: Stockholm, Sweden, 1970. (In Swedish)

53. Meadowcroft, J. Who is in charge here? Governance for sustainable development in a complex world. J. Environ. Policy Plan. 2007, 9, 299-314. [CrossRef]

54. Bulkeley, H.; Betsill, M. Rethinking Sustainable Cities: Multilevel Governance and the 'Urban' Politics of Climate Change. Environ. Politics 2005, 14, 42-63. [CrossRef]

55. Pontusson, J. Labor, corporatism, and industrial policy: The Swedish case in comparative perspective. Comp. Politics 1991, 23, 163-179. [CrossRef]

(C) 2016 by the authors; licensee MDPI, Basel, Switzerland. This article is an open access article distributed under the terms and conditions of the Creative Commons Attribution (CC-BY) license (http://creativecommons.org/licenses/by/4.0/). 